\title{
ICT Strategies of Democratic Intermediaries: A View on the Political System in the Digital Age
}

\author{
Arthur Edwards \\ Erasmus University Rotterdam \\ PB 1738, Room M8-25 \\ 3000 DR Rotterdam \\ tel. +31.10 .4082395$ \\ fax +31.10.4089099 \\ Edwards@fsw.eur.nl
}

\begin{abstract}
:
A conceptual framework is proposed for discussing the ICT strategies of intermediaries and their effects on democratic intermediation. The main line of reasoning is that both 'disintermediation' and 're-intermediation' have to be related to specific models of democracy and styles of citizenship. The linkage strategies of preference intermediaries, the supportive strategies of information intermediaries and the facilitative strategies of interaction intermediaries are discussed. The quality of democracy would be dependent on the interplay between different democratic practices, types of citizenship and intermediaries.
\end{abstract}

Key words: e-democracy, intermediaries, disintermediation, ICT strategies

Published in Information Polity 11 (2006) 163-176

IOS Press 
ICT Strategies of Democratic Intermediaries: A View on the Political System in the Digital Age

\section{Introduction}

Among the rhetorical claims that have been made about the impact of ICT on democracy is the argument that such technology can erode the position of intermediaries $[6,25]$. Some (early) ICT visionaries welcomed the prospect of such disintermediation of political parties, legislative representatives, traditional interest groups and journalists, as it would allow for an unbiased representation of citizens' demands. Grossman's view on the emerging 'electronic republic' is one example of this perspective, although he does acknowledge some dangers [24]. Others have argued that disintermediation is a major threat to democracy, as democratic intermediaries fulfil a variety of filter functions that are essential to the quality of democratic processes. According to this view, the fact that political tasks are 'delegated' to intermediaries (each of which has its own autonomy, perspectives and expertise) should be seen as positive [45].

Empirical evidence has cast doubts upon the proposition that the Internet encourages disintermediation. Traditional intermediaries appropriate ICT gradually as they attempt to strengthen their positions or to re-intermediate themselves in the public domain. Moreover, the Internet encourages the emergence of various new intermediaries, including voter information websites, moderated online discussion forums and mobilisation platforms on specific issues. Increased competition between intermediaries and an ensuing reconfiguration of positions between 'old' and 'new' intermediaries in democracy thus appears a more likely outcome than does the outright disappearance of intermediaries [1]. Although the literature on how various intermediaries appropriate ICT is developing rapidly $[8,10,12,19,38]$, no attempts have yet been made to develop a broader framework for analysing how ICT particularly the Internet - affects democratic intermediation. This paper sketches the contours of such a framework, focusing on one element that directly bears on the competition between intermediaries, the ICT strategies that intermediaries may pursue in their relationships with citizens. The argument in this paper proceeds from the proposition that democracy in network societies has differentiated itself into a range of practices that are situated in institutional arrangements, which correspond to 
specific models of democracy. In these practices, 'old' and 'new' intermediaries (whether Internet enabled or available only online) compete for citizens' attention. Furthermore, there is a differentiation in the orientations of citizens toward politics in terms of various styles of citizenship. The main line of reasoning in this paper is that disintermediation and re-intermediation have to be related to specific models of democracy and styles of citizenship. Section 2 provides an overview of the relevant institutional and social factors that must be included in such a perspective. Section 3 elaborates on democratic intermediation in the digital age, making distinctions between preference intermediaries, information intermediaries and interaction intermediaries. Section 4 outlines the main ICT strategies that these intermediaries pursue. Section 5 presents a number of conclusions for the nature and quality of democracy.

\section{A contextual approach to the use of ICT in democracy}

A growing literature within the study of ICT in politics and public administration addresses the interplay between human agency, technology, social processes and institutions (e.g.,1,3,17,27). I propose the concept of 'system of technologically mediated democratic practices' (STMDP) for considering the uses of ICT in democracy. This concept refers to Giddens' notion of a social system, which he defines as a set of situated activities of interrelated human agents, reproduced across time and space [21]. Because social systems can be identified at any level that is appropriate for specific research purposes, and because they may vary in their degree of 'systemness' [20,21], the STMDP concept refers to a wide array of phenomena, ranging from (practices within and around) formal organisations that have appropriated the Internet to digital discussion platforms or virtual advocacy networks. Systems of digitally mediated democratic practices have specific outcomes, such as the articulation of demands or the provision of information, as well as commentary on policy proposals. The interplay between human agents, technologies, democratic practices and democratic institutions is depicted in Figure1. ${ }^{1}$

\footnotetext{
${ }^{1}$ The design of Figure 1 is derived from the framework that is depicted in Figure 1.1 of Fountain [17]. For similar approaches, see: [27] and [40].
} 
[Figure 1 about here]

Human agents may figure into STMDPs as citizens, decision-makers or intermediaries. In line with Giddens [21, pp. 28-29], this perspective considers the frames of democracy that are held by citizens, decision-makers and intermediaries, and, at the level of interaction, the ICT strategies that these parties pursue. Technologies encompass the whole range of old and new media that human agents may use. As noted by Agre [1], 'political activities on the Internet are embedded in larger social processes and the Internet itself is only one element of an ecology of media'. Social systems have structure, which is understood as a set of social rules and resources. The structure of STMDPs is comprised of the institutional properties of the democratic regime within which these practices function. By democratic regime, I mean a configuration of institutional and organisational elements surrounding a specific decision-making mechanism [14]. As depicted in Figure 1, STMDPs reproduce the institutional properties of the democratic regime in which they function. While this may serve to enhance the institutional 'status quo', it may also lead to innovation. According to Snellen [46], ICT may elicit certain perceptions about opportunities for innovating democracy. Democratic intermediaries may develop new 'business models' for providing political information, articulating demands and performing other political functions.

On the basis of this framework, we develop a contextual approach to the disintermediation discussion, which allows for the possibility that an intermediary can be disintermediated in relation to one type of citizens, while maintaining its position in relation to another type, dependent on the ICT strategies that this intermediary pursues. This paper considers only the relation between intermediaries and citizens. To highlight the context in which intermediaries develop their ICT strategies, the two sections that follow provide further elaboration of the institutional context in terms of various democratic regimes or models of democracy, followed by a discussion of various frames of democracy that citizens may use to orientate themselves to politics.

\subsection{Democratic intermediation and models of democracy}

In modern network societies, collective decision-making has been dispersed or 'relocated' to networks of (semi-) public agencies (which span various levels of 
government), (semi-) private organisations, civil society organisations and companies which has led to the emergence of new forms of governance [41]. This has generated a concomitant diversification of the targets that citizens can attempt to influence beyond the nation-state or the governmental levels that exist within it [39]. The emergence of these new forms of governance has led some to argue that we are moving towards a 'post-parliamentary state', in which the centrality of parliaments has become eroded [5]. Figure 2 depicts various ways by which democratic influences can be channelled in network societies.

[Figure 2 about here]

I define democracy as 'responsive rule', with regard to the correspondence between acts of governance and the (equally weighted) interests of citizens with respect to those acts. Borrowed from Saward [43], this outcomes-based definition does not indicate a specific mechanism for achieving responsiveness. I do this by distinguishing six models of democracy, each of which specifies a mechanism, appropriate institutions and intermediaries for achieving responsiveness. The six models are as follows: representative democracy, direct democracy, deliberative democracy, pluralist democracy, associative democracy and client democracy.

Representative democracy and direct democracy involve citizens in the role of voter. In representative democracy, political parties aggregate citizen demands into political programmes, recruit candidates for legislative office and compete for electoral support. In contrast, direct democracy provides citizens with the opportunity to make political decisions on specific issues, with political leaders obligated to adopt these decisions. Deliberative democracy and pluralist democracy address citizens as active participants and co-producers of policies. Deliberative democracy includes all those arrangements in which citizens can discuss public issues with politicians and officials, who represent the agencies that are involved in public policies. Examples include participatory governance procedures, citizen juries and online policy exercises [9]. Pluralist democracy constitutes the arena in which interest groups, social movement organisations and other citizen initiatives articulate the concerns and demands of citizens and try to exert influence on political agenda setting and decision-making. Associative democracy and client democracy address citizens as users of services. Client (or consumer) democracy provides citizens with opportunities to give feedback 
on the delivery of public services [4]. In associative democracy, service provision is devolved to self-governing associations that function internally as representative, deliberative or direct democracies [26]. Within each of these types of democracy, ICT may be used to facilitate new forms of representation, political involvement and accountability [2,18]. Because the use of ICT creates opportunities for new intermediaries in democratic processes, (traditional) intermediaries may encounter more competition.

\subsection{Styles of citizenship}

As outlined by various authors, processes of modernisation have affected the political orientations of citizens, thus generating new demands in terms of political issues and forms of participation [30,39]. Modernisation has led to changes in value orientations, with expressive and moral orientations emerging alongside the more traditional instrumental and materialist orientations. Furthermore, citizens have acquired higher levels of personal skills that allow a wider repertoire of both institutional and noninstitutional forms of political participation. According to Richardson [42], citizens have an increased understanding of the 'efficacy of different modes of participation in post-industrial societies' (p.120). He also points to the reactive and episodic forms in which political participation occurs (p.133).

Little in-depth research has been conducted regarding the extent to which these tendencies have actually affected the orientations of citizens towards politics, including their conceptions of their political roles, civic duties and competences. Along these lines, a group of Dutch social researchers [37] identified four 'styles of citizenship': pragmatic-conformist, critical-responsible, deferent-dependent and inactive outsiders. 'Pragmatic' citizens are oriented primarily towards their own selfinterest, are reactive in their attitude towards government and politics and are highly selective in their information needs. Schudson's [44] model of 'monitorial citizenship' anticipated this style. Pragmatic citizens are inclined to perform the role of voter; while they can be mobilised for collective action, especially when their selfinterest is at stake, they are not easily motivated to participate as co-producers in forms of deliberative democracy. Their dominant media are the commercial broadcasting channels and newspapers, as well as the Internet. In contrast, 'criticalresponsible' citizens are more likely to have cosmopolitan or post-materialist 
attitudes. They are well informed, politically involved and can be recruited as active participants or co-producers of policies. Their dominant media are the quality newspapers and magazines, along with public broadcasting associations. They use the Internet for a variety of purposes and appreciate the interactive possibilities that it offers. 'Deferent-dependent' citizens are oriented primarily towards the local community. They adhere to traditional values and consider the role of voter as a civic duty. They can be mobilised as active citizens, but primarily for their local environment. Their local orientation is also reflected in their media usage. Although their material access to ICT has gradually increased, deferent citizens have difficulty keeping up with the information society. 'Inactive outsiders' are primarily convenience oriented. In general, they are not interested in politics. There are many non-voters in this category. They can be mobilized for protest action, if they perceive a major infringement on their immediate physical environment. Although 'outsiders' are Internet enabled, they tend to use this medium solely for their convenience and entertainment.

Apart from the somewhat normative undertone of the given designations ('deferent', 'responsible' etc.), the characterizations of these styles are rudimentary and especially lacking in their relative neglect of participation outside the realm of institutional politics and public administration. Further research into citizenship styles, including the ways in which people use various media, is needed in order to provide a more complete account of the relative importance of various sorts of intermediaries in the digital age.

\section{Types of democratic intermediaries}

In The Digital Divide, Norris [38] portrays ‘the virtual political system’ as 'mirroring the nondigital world' by following a conventional political system model in which political parties, interest groups, new social movements and the news media mediate between the citizens and the state (p. 96). This picture is helpful for describing how the Internet affects political participation, interest representation and information provision in liberal democracies. This view may tend to neglect a number of new forms, however, particularly those that exist only online (and that have not moved 
online). A more complete account requires a new approach to the study of democratic intermediation in the digital age.

In modern democracies, citizens delegate a variety of complex tasks involving the articulation of preferences, provision of political information and decision-making to intermediaries. The principal form of delegation in democracy involves the popular election of political representatives. Within the context of pluralist interest representation, many organisations engage in 'credit card participation', in which the members pay contributions, thereby 'contracting out' their campaigning and lobbying tasks to professionals or activists [42]. Research on referenda has indicated that voters may rely on the endorsements of political parties and interest groups [33]. With regard to the gathering of information, instead of monitoring the activities of their representatives directly, citizens tend to rely on third-party testimonies, as when journalists and other actors act as information intermediaries. Together with participation, delegation forms the foundation of democracy [34].

Political intermediaries are agents who perform a connecting function between citizens and political decision makers, or between citizens and other actors in the public domain. ${ }^{2}$ Because the focus of this paper is on relations between citizens and intermediaries in which citizens hold the principal position, this discussion does not address the relation between intermediaries and decision makers. Intermediation can take one of three forms:

- Articulating and aggregating political demands. Preference intermediaries, particularly political parties, interest groups and elected representatives, specialise in these kinds of tasks.

- Providing information. Citizens need information in order to perform the political roles of voter, active participant or service user. In addition to their own experiential information, citizens tend to rely on information intermediaries, who select, interpret or comment on primary information.

- Facilitating interactions. The trend whereby more and more collective decision-making processes are taking place in networks has increased the importance of the roles of various interaction intermediaries. Interaction intermediaries fulfil facilitator roles in deliberation (moderators [15])

\footnotetext{
${ }^{2}$ The identity of the 'decision makers' depends on the context. While elected representatives fulfil an intermediary role in the relationship between citizens and the executive, they may figure as decision makers in other relationships.
} 
negotiation (mediators [36]), exchange (e.g., vote swapping) or transactions (e.g., facilitating the agreement and settlement phases in service transactions, [23]).

Strictly speaking, this typology refers to functions and not to agents, as a specific intermediary can fulfil several functions in combination. Intermediary functions can be performed in both the physical and the virtual domain. A distinction can be made between intermediaries that originate in the physical domain and those who emerge in cyberspace. As increasing numbers of intermediaries from the first category move online, and as 'virtual' organisations become increasingly likely to engage in face-toface encounters, the distinction between 'physical' and 'virtual' organisations is becoming a matter of degree. Cybermediaries (i.e., digital intermediaries), however, operate exclusively in cyberspace. These entities are comprised of software systems that perform their functions without human interference. Voting-indicator tools, which are software programmes that provide users with recommendations for political parties or candidates, are one example of a cybermediary. Although the most obvious location of human agency in this example is in the role of the users, it is also manifested in the design of cybermediaries. In this sense, the designers of cybermediaries could be considered as a kind of 'meta-intermediary'. The advent of ICT in political processes has been accompanied by a shift towards mixed constellations of Internet-enabled (traditional) intermediaries and new intermediaries that are available only online. For example, Internet-enabled political parties, candidates and elected representatives can be encountered within representative democracy, as can new intermediaries that started their activities on the Internet and that can be reached almost exclusively through the Internet. Examples of the latter include web-logs, voting-indicator tools and vote-swapping websites. Edwards [16] describes how the Internet favours the extension of the organisational infrastructure of a social movement within pluralist democracy. Using the example of the Dutch women's movement, he shows that, in addition to existing associations that have moved online, new virtual organisations and cybermediaries have emerged. These new entities include specialised information portals and platforms for mobilisation and lobbying, as well as platforms for discussion and the exchange of knowledge and services. 


\section{Democratic intermediaries and their ICT Strategies}

Because preference intermediaries perform the most prominent role in political processes, this section begins with a discussion of the linkage strategies of political parties and interest groups, followed by a discussion of the supportive strategies of information intermediaries and the facilitative strategies of interaction intermediaries. A further distinction between function-enhancing strategies (which are directed towards the existing 'core business' of the intermediary) and function-expanding strategies allows the consideration of various patterns of competition. For example, by expanding their activities to include preference intermediation, information intermediaries and interaction intermediaries may pose additional competition for (traditional) preference intermediaries.

\subsection{Preference intermediaries and their linkage strategies}

The core business of preference intermediaries is to provide political linkage (Fig. 3). Political linkage establishes a connection between two elements, the wishes of citizens and the decisions of public leaders [31]. As indicated by Luttbeg's [35] definition of linkage, (i.e., a 'mechanism that allows public leaders to act in accordance with the wants, needs and demands of their public'), political linkage can be established in a variety of ways. First, the connection can be established with or without intermediaries. Second, the underlying mechanism can be coercive or noncoercive. The electoral process is the quintessential example of a coercive linkage mechanism. Non-coercive mechanisms are represented in Luttbeg's 'sharing model' and 'role-playing model'. In the sharing model, leaders give expression to public demands, as they share their preferences with the public. The role-playing model is based on a normative belief on the part of leaders that they should give expression to the desires and concerns of the public.

The presence of intermediary organisations introduces several 'phases' in a linkage chain. A three-step model emerges when the linkage chain between citizens, intermediary organisations and public leaders is taken into account and the organisation's relationship with its members is distinguished from its relationship with the wider public. First, intermediaries serve as agencies within which citizens 
participate in making the organisation's policies. As members of political parties and interest groups, they fulfil this role by formulating the organisation's programme and choosing its representatives or candidates. In a discussion of linkage by political parties, Lawson [31] refers to this process as 'participatory linkage'. Second, intermediaries provide certain means with which the public can control the functioning of these organisations in the articulation and aggregation of interests. Although Lawson refers to this process as 'electoral linkage', I prefer the term 'representative linkage', as it can also be applied to interest groups. ${ }^{3}$ In the latter case, representative linkage refers to such 'thin' forms of activism as (e-) petitioning and donating, by which interest groups mobilise support for their policies. Third, intermediaries serve as agencies for ensuring that public decision makers are responsive to the desires of citizens. Interest groups accomplish this by lobbying, bargaining or protest politics, while political parties do so through parliamentary control. I refer to this as 'policy-directed linkage'. A number of ICT strategies can be proposed for each of these types of linkage. Because the focus of this paper is limited to the relationship between citizens and intermediaries, I address only participative and representative linkages.

Löfgren and Smith [32] develop a typology for the ICT strategies of political parties. The typology includes the traditional mass party and the currently more dominant cartel party, in addition to two emerging strategies: a consumerist strategy (which represents 'an extreme form of the cartel party') and a grassroots strategy. The classical mass party provides both participatory and representative linkage, whereby elected representatives are seen as delegates of well-defined interests rather than of the electorate at large. A clear distinction between members and non-members is a central feature of the mass-party strategy. Key ICT applications include those that broaden the range or would “widen members' input to the policy process" and "would allow for mobilisation of the members when needed and swift dissemination of information from the leadership” [32, p.44-46]. For non-members, such websites fulfil a service function and operate as outlets for information.

The cartel party strategy emphasises representative linkage, whereby the party is accountable to the electorate at large, rather than to its members. Political marketing tactics are more important in this strategy, and the distinction between

\footnotetext{
${ }^{3}$ Löfgren and Smith [32] use the term 'representative linkage' as an alternative for 'electoral linkage'.
} 
members and non-members is blurred. Dominant ICT applications are 'mainly concerned with the campaigning and narrowcasting facilities of the new technology'. Consumerist parties expend even more effort to anticipate and discern the preferences of voters. In the inter-election period, they offer individuals opportunities to express their discontent about public services, although this input tends to be treated as marketing information. The grass-roots strategy is based "upon the participatory ethos of new popular movements such as environmentalists and peace activists” [32, p.49]. The uses of ICT are directed at facilitating "a new public sphere in which deliberation and the creation of new identities is conceivable” [32, p.49].

This typological approach to ICT usage by political parties could also inform the study of the ICT strategies of interest groups and social movement organisations. A wide range of specific strategies is available to (public) interest groups for recruiting members and involving them in their political activities. Jordan and Maloney [28] refer to the diversity of ideological and tactical orientations among environmental groups. They characterise a large part of the environmental movement as a 'protest business', which pursues strategies resembling those of the cartel party in terms of reliance on supporters rather than members, centralisation of policy-making and the usage of professional marketing strategies. With regard to 'memberless groups' (e.g., Greenpeace) they argue “there is little in participatory terms which distinguishes them from political parties” [28, p.187]. Grass-roots participation is restricted to the small ecological and direct-action fraction of the movement (28, pp. 30-31]. Research on how ICT contributes to the strategies that are developed by social movement organisations, indicate that these groups tend to use ICT primarily to distribute information and support mobilisation. Interactivity is largely limited to feedback opportunities and correspondence by e-mail [12].

Their emphasis on participatory or representative linkage strategies clearly leads preference intermediaries to make different choices. In other words, political parties and (public) interest groups offer a variety of options for interest representation and participation, each of which attracts a different public. To the extent that the citizenry shares the notion of a political division of labour, representative linkage constitutes an appropriate mode of political intermediation, which is particularly well suited to the pragmatic-conformist style of citizenship indicated above. Pragmatic citizens will tend to combine various 'thin' action forms, such as voting, (e-)petitioning and donating. They will make pragmatic choices in 
terms of which intermediaries to address for which issues. According to this line of reasoning, the disintermediation of political parties in their representative linkage function is not very likely (except for the category of the 'inactive outsiders'), if the representative linkage they provide has substance with regard to at least a few salient issues that are important to the citizens. With regard to participative linkage political parties and interest groups will primarily appeal on critical-responsible citizens, dependent on attractive grass-roots strategies. Neighbourhood-based organisations could mobilize deferent-dependent citizens, using grass-roots strategies, with easy accessible Internet facilities, and combining these with face-to-face interactions.

\subsection{Information intermediaries and their supportive strategies}

Many new information intermediaries have emerged since the advent of the Internet. They include various types of voter-information websites (e.g., the well-known voting-indicator tools), alternative news platforms that are related to social movements, web-logs with interactive features, online client communities and other websites that support client choices. Information intermediaries assemble information from decision-makers and from other actors that are involved in governance practices (see Fig. 4). Three strategies are available for enhancing the information function of these intermediaries: (a) manipulating the information base, (b) expanding the range of users and (3) adopting multi-channel approaches. The discussion below addresses these strategies with reference to voting-indicator tools and websites that support client decisions.

It can be argued that voting-indicator tools have the potential to improve the quality of electoral linkage, depending on their power to generate 'correct' voting advices. To date, most voting-indicator tools are restricted to matters of policy content. It is possible, however, for voters to have multiples reasons (e.g., a party's ideology, personal characteristics of its candidates and various strategic reasons) for choosing a particular party. By trying to include these factors, designers could broaden the information base of voting-indicator tools. Because their development is still in an incipient phase, competition between different versions of voting-indicator tools can be expected to increase. The second strategy is aimed at expanding the number of users. The success of the Dutch StemWijzer voting-indicator tool, which provided two million voting recommendations in the 2002 election period, was partly 
due to syndication agreements that were made with national newspapers and broadcasting associations, Internet providers and the Ministry of the Interior. In a multi-channel strategy, voting-indicator tools can be used in television 'infotainment' formats or similar applications.

Within the context of client democracy, Griffin and Halpin [23] examine the role of the local authority website as an intermediary that links consumers to the products and services of other organisations. They evaluate the websites with respect to two life events: (a) the selection of a local school and (b) finding a hotel to stay as a tourist. The first life episode lies within the realm of public service delivery. Griffin and Halpin identify various options that would allow local authorities to develop into 'mature' information intermediaries. First, websites could broaden their information base by including information about private schools, or by providing information about schools outside of their administrative areas (for parents living in communities that are served by schools from two or more local authorities). Websites could also provide contextual information from schools or government agencies that would assist parents in their evaluation of schools. Specific sub-strategies include 'matching' (i.e., helping users to identify their needs and matching each service to these requirements) and 'aggregating' (i.e., including such related information services as the contact details of council members).

Some websites that originated as information intermediaries have extended their role to other functions. In their account of patients' online communities, Josefsson and Ranerup [29] indicate that these communities originated as information intermediaries, later adding functionalities for interaction with fellow patients. They also began to perform as preference intermediaries by trying to influence public opinion in order to affect the way patients are treated by the healthcare system.

Several disintermediation and re-intermediation scenarios are conceivable in relation to specific styles of citizenship. An example is the complete disintermediation of the traditional news media among young, pragmatic citizens, while these media would retain their strongholds among 'responsible-critical' citizens. Traditional media develop several strategies to counter this scenario. In contrast, weblogs could attract pragmatic citizens and also 'outsiders'. Löfgren and Smith [32] mention votingindicator tools as examples of the consumerist party strategy, although political parties do not generally provide these tools themselves. The use of these tools, however, can be linked to the pragmatic-conformist style of citizenship. Voting- 
indicator tools are particularly attractive to pragmatic citizens, as they reduce the information costs of comparing election platforms.

\subsection{Interaction intermediaries and their facilitative strategies}

Experiments in several countries have been carried out with online deliberative policy exercises in which citizens act as co-producers of public policy [9]. Experience has shown that these experiments attract few participants and that participation is often skewed to the more highly educated. In terms of citizenship styles, the experiments appear to attract critical-responsible citizens. Deliberative arrangements, however, should not be discarded as avenues for democratic interest representation. First, some studies indicate that this 'participation elite' of critical-responsible citizens expresses a greater diversity of views than might be expected, given the social homogeneity of this group. ${ }^{4}$ Second, participation from categories that are expected to be underrepresented can be stimulated by specific measures in the management of these exercises. More locally oriented 'deferent' citizens could perhaps be mobilized if the issues are related to their life-world, if the technologies are user-friendly, and if online discussion is combined with face-to-face meetings [13].

Awareness is growing concerning the importance of moderation in online discussions. In an exposition of moderator roles, Edwards [15] distinguishes three main functions for the management of online discussions concerning public issues:

(1) The strategic function: establish the boundaries of the discussion and embed it within the political and organisational environment;

(2) The conditioning function: set conditions and provisions for the discussion (e.g., information provision and representation of affected interests).

(3) The process function: further the progress of the discussion as a collective, purposeful activity.

Moderators are involved primarily in the process function. As interaction intermediaries they invest considerable effort in enhancing the interactivity of the

\footnotetext{
${ }^{4}$ Dutch studies: See Van der Tuuk [47], who coined the term 'representative elite', and recently Van Doorn and Schippers [13] in their research on online policy exercises. It has to be emphasized that these studies looked at government-run discussions, not at Usenet newsgroups as recently investigated by Davis [11].
} 
discussion, particularly in situations in which they encourage politicians and other institutional actors to react to the contributions of citizens (see Fig. 5).

Moderators can expand their involvement in online discussions by taking roles within the conditioning and strategic functions. Within the conditioning function, they can act as information intermediaries by inviting public agencies, interest groups and political parties to provide information or state their policy stances on particular subjects. Moderators can also assume responsibility for communicating the results of the discussion to decision makers, thereby extending their roles to include preference intermediation. Moderators can provide representative linkage by consolidating the results of a discussion into a document that is commonly agreed upon by the participants.

\section{Conclusion and reflections}

This paper has addressed the question of how ICT affects the position of intermediaries in democracy. Counter to the proposition that ICT contributes to disintermediation, I have argued that the disintermediation discussion has to be related to specific models of democracy and styles of citizenship. At the institutional level, democratic polities are becoming increasingly differentiated with respect to various models of democracy. The new institutional arrangements that are emerging provide a variety of niches for new intermediaries. From a socio-cultural perspective, there is a differentiation in the orientations of citizens towards politics. People develop various frames of democracy or styles of citizenship, each of which involves a different conception of political roles and civic duties. These styles of citizenship affect citizens' patterns of democratic involvement, their information behaviour and the relationships they seek with intermediaries.

Against this background, I have sketched a general framework that focuses on the ICT strategies that are available to intermediaries as they compete for citizen attention. The competition between democratic intermediaries can be studied at two analytical levels, each with a unique bearing on disintermediation. Focusing on preference intermediation, we can look, first, at the competition occurring between intermediaries that belong to the same category within the same model of democracy. An example of competition within this arena would be competition between 
individual political parties. Competition between members of the same 'species', however, does not lead to disintermediation of the species; instead, competition may invigorate the species, as a result of imitation and selection of promising ICT uses. Second, competition occurs between different types of preference intermediaries, including those intermediaries that expanded their functions to preference intermediation. In relation to styles of citizenship we can point to the competition between political parties, interest groups, protest networks, moderators, consumer groups and online communities. In this context, there is a chance of a partial disintermediation of an intermediary, 'partial' in relation to a specific style of citizenship, in participative linkage, representative linkage or both.

One of the central notions underlying representative democracy is the 'division of labour' between voters, political parties and elected representatives. In the differentiated democratic polity sketched in this paper, there is rather a differentiation in terms of various democratic practices (STMDPs) involving different intermediaries and types of citizens. This points to a much wider branched pattern of 'virtual political delegation' between democratic publics and 'their' intermediaries. The quality of democracy would be dependent on the interplay between these practices, publics and intermediaries, and on the checks and balances they provide in governance. For elected representatives, these dynamics involve both threats and opportunities. The erosion of the centrality of representative institutions in the network society places the position of representatives under pressure. They may stand up to these challenges, however, by re-inventing (and expanding) their roles as interaction intermediaries and fulfilling facilitator roles: "In a world in which direct and participatory democracy coexists with representative democracy the role of the representative changes, and becomes one of ring holder, advocate, broker- listening to and bringing together the views of different communities. The job of the representative becomes that of integrating different sorts of democracy and different sources of democratic legitimacy” [22, p.135]. ICT provides representatives with new channels of connection within the network society. The models of democracy provide different communicative infrastructures for new forms of representative politics.

For the researcher interested in the interplay between the various democratic practices, we would recommend a shift to the study of whole policy domains, such as public health and housing, focusing on how specific publics operate in this domain, how they specialise in (or combine) different action repertoires, in their role of voters, 
co-producers of policies or service users, their adoption of ICT, and how they respond to the ICT strategies of intermediaries. The effects of ICT strategies on democratic intermediation can be explored by taking a longitudinal approach [7].

\section{References}

[1] Ph. E. Agre, Real-Time Politics: The Internet and the political process, The Information Society, 18 (2002), 311-331.

[2] A.V. Anttiroiko, Introduction to Democratic e-Governance, in: eTransformation in Governance. New Directions in Government and Politics, M. Mälkiä,

A.V.Anttiroiko, and R. Savolainen (Eds), Idea Group, Hershey, 2004, pp. 22-49.

[3] V. Bekkers \& V. Homburg (Eds.), The Information Ecology of E-Government, IOS Press, Amsterdam etc., 2005.

[4] Chr. Bellamy and J.A. Taylor, Governing in the Information Age, Open University Press, Buckingham, Philadelphia, 1998.

[5] Chr. Bellamy,and Ch. D. Raab, Wiring up the deck-chairs?, in:

Parliament in the Age of the Internet, S. Coleman, J.Taylor and W. van de Donk, eds., Oxford University Press, Oxford,1999, pp.156-172.

[6] C. Bryan, R. Tsagarousianou, and D. Tambini, Electronic Democracy and the Civic Networking Movement in Context, in: Cyberdemocracy: Technology, Cities and Civic Networks, in: R. Tsagarousinou, D. Tambini, and C. Bryan, eds., Routledge, London and New York, pp.1-17.

[7] A.M. Chircu and R.J. Kauffman, Strategies for Internet middlemen in the intermediation/disintermediation/reintermediation cycle, Electronic Markets, 9 (1/2) (1999), 109-117.

[8] S.Coleman, J. Taylor and W. van de Donk (Eds.), Parliament in the Age of the Internet, Oxford University Press, Oxford, 1999.

[9] S. Coleman and J. Gøtze, Bowling together: online public engagement in policy deliberation, Hansard Society, 2001.

[10] R. Davis, The Web of Politics: The Internet's Impact on the American Political System, Oxford University Press, Oxford, 1999.

[11] R. Davis, Politics Online: Blogs, Chatrooms and Discussion Groups in American Democracy, Routledge, London and New York, 2005. 
[12] W.B.H.J. van de Donk, B. Loader, P. Nixon and D. Rucht (Eds.), Cyberprotest: New Media, Citizens and Social Movements, Routledge, London and New York, 2004.

[13] K. van Doorn and E. Schippers, Burgers, overheid en digitale debatten, Eburon, Delft, 2003.

[14] K. Eder, Die Dynamik demokratischer Institutionenbildung. Strukturelle Voraussestzungen deliberativer Demokratie in fortgeschrittenen Industriegesellschaften, in: Politische Institutionen im Wandel; Kölner Zeitschrift für Soziologie und Sozialpsychologie (35) (1995), B. Nedelman (Ed.), 327-345.

[15] A.R. Edwards, The moderator as an emerging intermediary: the role of the moderator in Internet discussions about public issues, Information Polity 7 (1) (2002), 3-20.

[16] A.R. Edwards, (2004). The Dutch women's movement online: Internet and the organizational infrastructure of a social movement, in: Cyberprotest: New Media, Citizens and Social Movements, W.B.H.J. van de Donk, B. Loader, P. Nixon and D. Rucht (eds.), Routledge, London and New York, 2004, pp.183-206.

[17] J. Fountain, Building the Virtual State, The Brookings Institute, Washington DC, 2001.

[18] P.H.A. Frissen, Representative democracy and information society: a postmodern perspective, Information Polity, 7 (2002), 175-183.

[19] R. Gibson, P. Nixon, and S. Ward, Net Gain? Political Parties and the Impact of New Information and Communication Technologies, Routledge, London and New York, 2003.

[20] A. Giddens, New Rules of Sociological Method, Polity Press, Cambridge, 1976.

[21] A. Giddens, The Constitution of Society, Polity Press, Cambridge, 1984.

[22] S. Goss, Making Local Governance Work, Palgrave, Houndmills (Basingstoke), 2001.

[23] D.Griffin, and E. Halpin, Local Government: A digital intermediary for the information age?, Information Polity 7 (2002), 217-230.

[24] L.K. Grossman, The Electronic Republic. Reshaping Democracy in the Information Age, Viking, Harmondsworth, 1995.

[25] K.L. Hacker, and J. van Dijk, What is digital democracy?, in: Digital Democracy. Issues of Theory and Practice, K.L. Hacker \& J. van Dijk (eds.), Sage Publications, London, 2000, pp. 1-10. 
[26] P. Hirst, Associative Democracy, Polity Press, Cambridge, 1994

[27] J. Hoff, Technology and social change: the path between technological determinism, social constructivism and new institutionalism, in: Democratic Governance and New Technology. Technologically Mediated Innovations in Political Practice in Western Europe, J. Hoff, I. Horrocks, and P.W. Tops (eds.), Routledge, London and New York, 2000, pp.13-32.

[28] G. Jordan, and W. Maloney, The Protest Business, Manchester University Press, Manchester, 1997.

[29] U. Josefsson, and A. Ranerup, Consumerism revisited: the emergent roles of new electronic intermediaries between citizens and the public sector, Information Polity 8 (2003), 167-180.

[30] H.D. Klingemann, and D. Fuchs, Citizens and the State, Oxford University Press, Oxford, 1995.

[31] K.Lawson, When Linkage Fails, in: When Parties Fail. Emerging Alternative Organizations, K. Lawson and P.H. Merkl (Eds.), Princeton University Press: Princeton, 1988.

[32] K. Löffgren and C. Smith, Political parties and democracy in the information age, in: Net Gain? Political Parties and the Impact of New Information and Communication Technologies, Gibson, R., P. Nixon, and S. Ward (Eds.), Routledge, London and New York, 2003, pp. 39-52.

[33] A. Lupia, Shortcuts versus encyclopedias; information and voting behavior in California insurance reform elections, American Political Science Review, 88 (1) (1994), 63-76.

[34] A. Lupia, and M.D. McCubbins, The Democratic Dilemma: Can Citizens Learn What They Need to Know?, Cambridge University Press, Cambridge, 1998.

[35] N.R. Luttbeg, Public Opinion and Public Policy, The Dorsey Press, Homewood, 1968.

[36] O. Märker, and B. Schmidt-Belz, Online Mediation for Urban and Regional Planning, in: Computer Science for Environmental Protection, A.B. Cremers and K. Greve (eds.), Metropolis Verlag, Marburg, 2000, pp. 158-172.

[37] Motivaction, Burgerschapsstijlen en overheidscommunicatie (Commissie Toekomst Overheidscommunicatie), Amsterdam, 2002.

[38] P. Norris, Digital Divide. Civic Engagement, Information Poverty, and the Internet Worldwide, Cambridge University Press, Cambridge, 2001. 
[39] P. Norris, Democratic Phoenix. Reinventing Political Activism, Cambridge University Press, Cambridge, 2002.

[40] Parvez, Z., Local Democracy Shaping E-Democracy, in: R. Traunmüller (Ed.), Electronic Government, Second International Conference, EGOV, Prague, Czech Republic, September 1-5, 2003, Proceedings, Springer, Berlin etc., pp. 63-68 [41] R. Rhodes, Understanding Governance, Open University Press, Buckingham, 1997.

[42] J. Richardson, The market for political activism: interest groups as a challenge to political parties, West European Politics, 18(1) (1995), 116-139.

[43] M. Saward, The Terms of Democracy, Polity Press, Cambridge, 1998.

[44] M. Schudson, The Good Citizen: A History of American Civic Life, The Free Press, New York, 1998.

[45] A.L. Shapiro, The Control Revolution. How the Internet is Putting Individuals in Charge and Changing the World We Know, The Century Foundation, New York, 1999.

[46] I.Th. M. Snellen, ICT: a revolutionizing force in public administration?, Informatization in the Public Sector 3 (1994), 283-304.

[47] B. van der Tuuk, De representatieve elite. Een onderzoek naar het effekt van selektieve deelname bij inspraak, IVA, Tilburg, 1982. 
Figure 1: A contextual approach to the use of ICT in democracy ('Systems of digitally mediated democratic practices')

Figure 2: Democratic arrangements in the network society

Figure 3: Preference intermediaries

Figure 4: Information intermediaries

Figure 5: Interaction intermediaries 


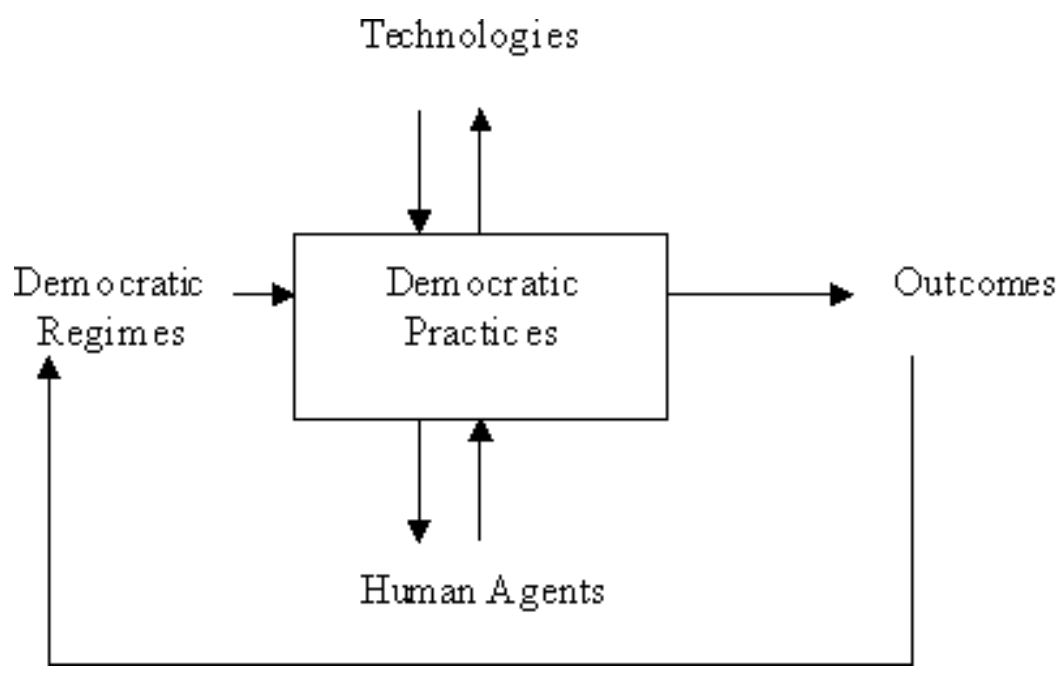

Fig. 1: A contextual approach to the use of ICT in democracy ('Systems of technologically mediated democratic practices') 


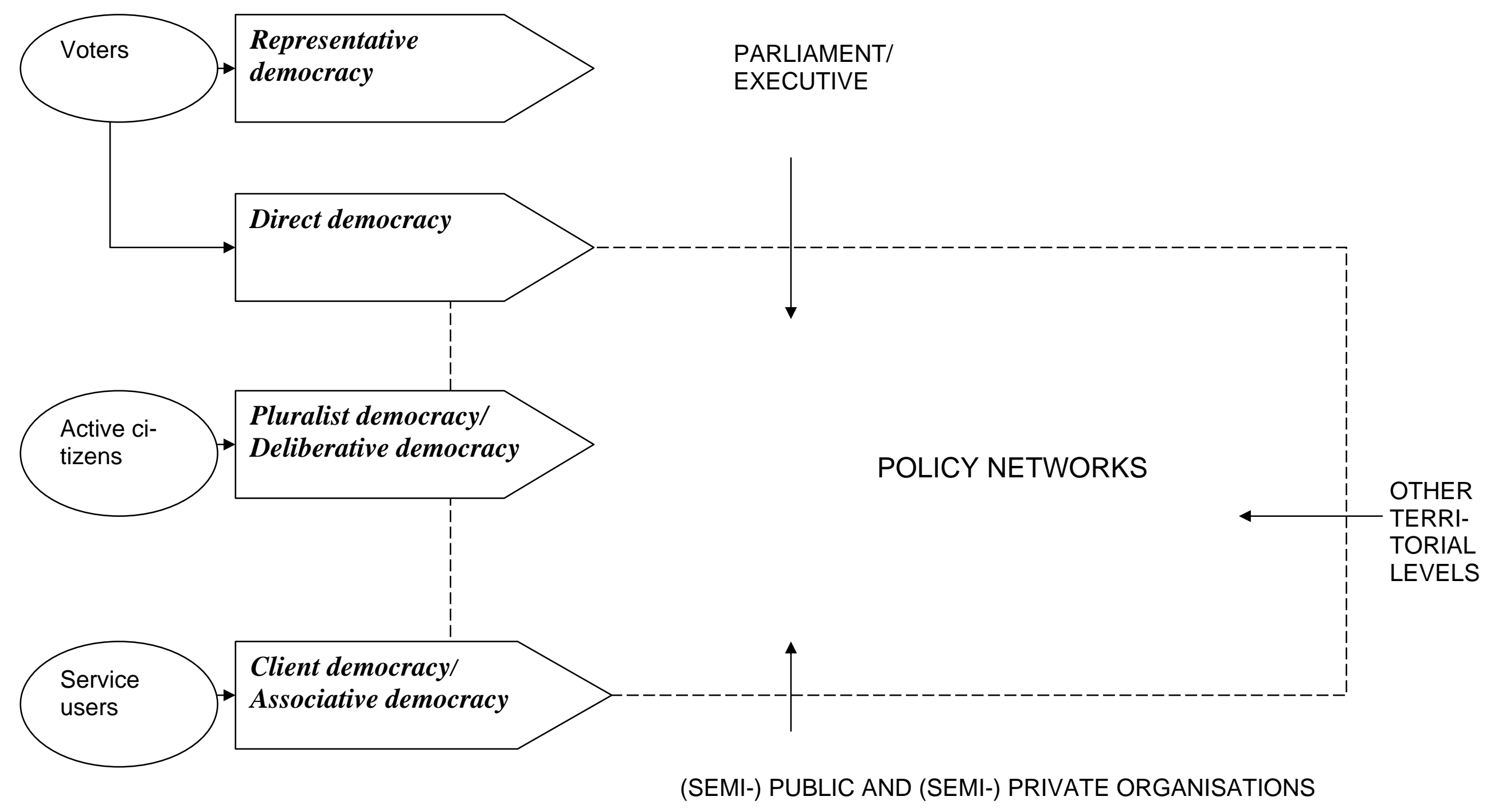

Fig. 2: Democratic arrangements in the network society 
Decision-makers

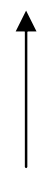

Preference intermediaries

$\uparrow$

Citizens

Fig. 3: Preference intermediaries 


\section{Decision-makers}
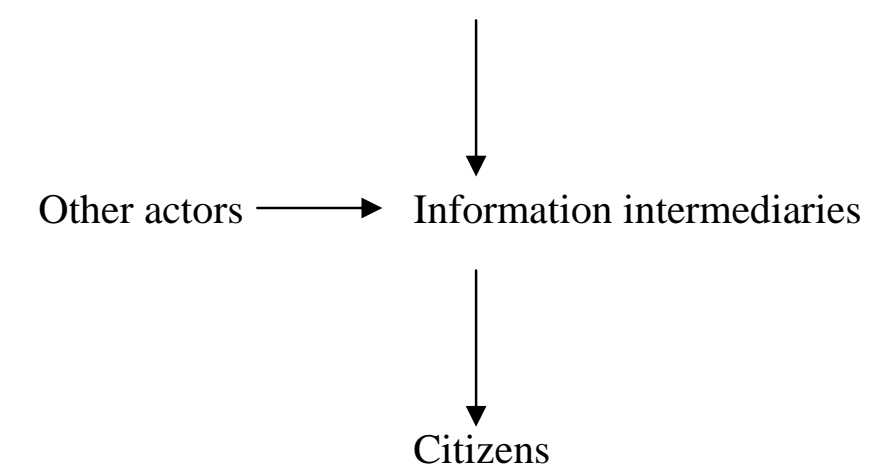

Fig. 4: Information intermediaries 


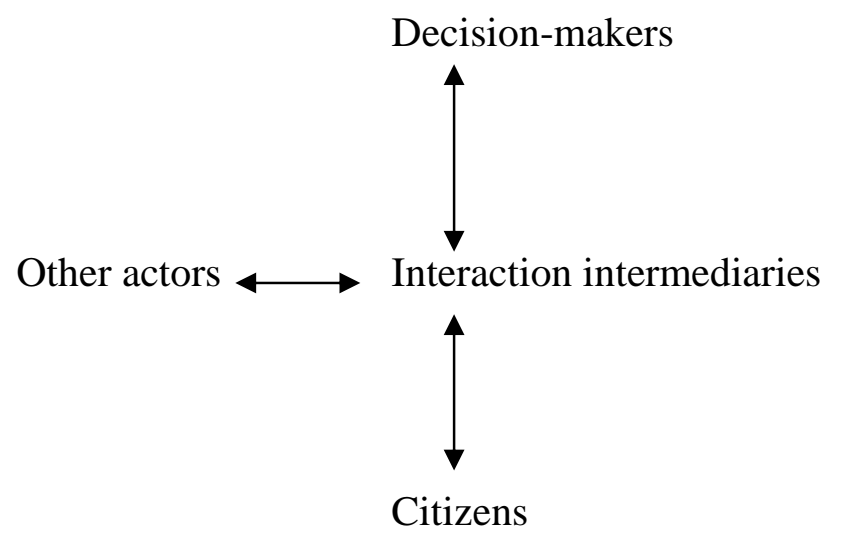

Fig. 5: Interaction intermediaries 